\title{
Usefulness of Autofluorescence Video-Monitoring to Enhanced Localization of Parathyroid Glands
}

\author{
Sung Won Kim ${ }^{1,2}$, Yoon Soo Seo ${ }^{1}$, Hyoung Shin Lee, \\ Yikeun Kim ${ }^{3}$, Yeh-Chan $\mathrm{Ahn}^{3}$, and Kang Dae Lee ${ }^{1,2}$ (D) \\ ${ }^{I}$ Department of Otolaryngology-Head and Neck Surgery, Kosin University College of Medicine, Busan; and \\ ${ }^{2}$ Innovative Biomedical Technology Research Center, Busan; and \\ ${ }^{3}$ Department of Biomedical Engineering and industry 4.0 Convergence Bionics Engineering, Pukyong National University, Busan, Korea
}

\author{
부갑상선 국소화를 위한 자가형광 비디오 모니터링의 유용성 \\ 김성원 ${ }^{1,2} \cdot$ 서윤수 $^{1} \cdot$ 이형신 $^{1,2} \cdot$ 김이근 $^{3} \cdot$ 안예찬 $^{3} \cdot$ 이강대 $^{1,2}$ \\ 고신대학교 의과대학 이비인후-두경부외과학교실, ${ }^{1}$ 동남권 의공학 임상혁신 융합 연구단, \\ 부경대학교 의공학과 및 4차산업 융합바이오닉스 공학과 ${ }^{3}$
}

\footnotetext{
Received July 22, 2019

Revised November 17, 2019

Accepted December 11, 2019

Address for correspondence

Kang Dae Lee, MD, PhD

Department of Otolaryngology-Head and Neck Surgery, Kosin University

College of Medicine,

262 Gamcheon-ro, Seo-gu,

Busan 49267, Korea

Tel $+82-51-990-6470$

Fax $+82-51-245-8539$

E-mail kdlee59@gmail.com
}

Background and Objectives Near-infrared (NIR) fluorescence photo imaging provides real time parathyroid anatomy enhancement. Moreover, autofluorescence enables intraoperative virtual reality parathyroid exploration of the optical characteristics of the parathyroid gland. This study was performed to demonstrate the new technique of visualizing the parathyroid gland using video-guided autofluorescence during thyroid and parathyroid surgery and to evaluate the outcomes. This is the first study that introduces the video-monitoring technique for intraoperative parathyroid mapping.

Subjects and Method A total of 26 patients underwent 18 total thyroidectomies and 8 hemithyroidectomies in 2016. Fifty-six parathyroid glands were enrolled in this study. Surgery was performed by NIR video-monitoring via thyroid lateral side dissection to find the parathyroid tissues and extract the thyroid glands. With the operation room light turned on, the parathyroid glands were identified by the video-guided autofluorescence detection technique carried out in 3 stages (P1, P2, and P3), which are imaging with surgeon's eyes before parathyroids exposure (P1), after identification (P2), and in extracted specimen (P3).

Results The parathryoid autofluorescence could be video-monitored in real time by our NIR camera system with the indoor room light turned on. Of the total 56 parathyroids, 52 were detected by fluorescence. Of these, the location of 43 glands were predicted by using the high signal in a before-exposure state and the glands were confirmed as containing parathyroid tissues [in P1, sensitivity $=82.69 \%$, positive predictive value $(\mathrm{PPV})=100.00 \%$ ]. Of the nine glands that did not show high signals in $\mathrm{P} 1$, seven glands visually showed fluorescence signals (in $\mathrm{P} 1$ and $\mathrm{P} 2$, sensitivity $=96.15 \%$, $\mathrm{PPV}=100.00 \%$ ). One of the two glands that showed high signals in the extracted tissue was identified as parathyroid, but the other one was proved not by histologic examination by despite high intensity fluorescence signal (in P1-P3, sensitivity $=100.00 \%$, PPV=98.08\%). The accuracy of videoguided parathyroid mapping in $\mathrm{P} 1, \mathrm{P} 2$, and $\mathrm{P} 3$ were $83.93 \%, 96.43 \%$, and $96.43 \%$, respectively.

Conclusion This is the first study that demonstrates the parathyroid gland autofluorescence as a real-time video-monitoring technique and shows that it could be applied to real surgery. Although parathyroid autofluorescence is a phenomenon seen in the invisible wavelength, our data suggest that the operator can see the parathyroid fluorescent signal in real time on the videomonitor. This technique could help the operator to predict the gland location and preserve them safely. Korean J Otorhinolaryngol-Head Neck Surg 2020;63(12):586-93

Key Words Autofluorescence · Near-infrared · Parathyroid gland · Thyroidectomy.

This is an Open Access article distributed under the terms of the Creative Commons Attribution Non-Commercial License (https:/creativecommons.org/licenses/by-nc/4.0) which permits unrestricted non-commercial use, distribution, and reproduction in any medium, provided the original work is properly cited. 


\section{서 론}

갑상선 수술 후 저칼슘혈증은 가장 흔한 합병증 중의 하나 이다. 그 빈도는 임상적으로 증상이 있는지, 또는 혈중 칼슘 농도나 부갑상선 호르몬의 수치가 감소하느냐에 따라 다양하 게 보고되고 있지만, 수술 후 일시적으로는 $20 \%$, 영구적으로 는 1 2\%에서 부갑상선 기능저하증을 경험한다고 하며, 경험 이 부족한 술자뿐만 아니라 비교적 경험이 많은 술자에서도 의도하지 않게 부갑상선이 적출되는 경우는 $15 \%$ 에 이른다고 한다. ${ }^{1)}$

기본적으로, 수술 후 부갑상선 기능저하증을 예방하기 위 해서는 가장 먼저 해야 할 일은 수술 중에 부갑상선 조직을 확인하는 것이고, 그 다음으로 기능성을 평가할 수 있어야 한다. 그러나, 부갑상선은 크기가 매우 작고 색깔이 주변의 장기와 비슷하며 지방조직에 묻혀 있는 경우가 많아서, 이를 보존할 수 있는 다양한 술식이 소개되었지만 최근까지도 술 자의 직관적인 방법으로 부갑상선 조직을 확인하고 미세한 혈관이 잘 보존되었는지를 주관적으로 평가하고 있다. 그래 서 경험이 쌓여 숙련된 외과의사조차도, 수술 중에 부갑상선 을 쉽게 구별할 수는 있지만 수술 후 혈류가 잘 유지되어 정 상적으로 기능을 할지 확신하지 못할 때도 있는 실정이다. ${ }^{23}$

최근에 근적외선 형광영상을 부갑상선을 찾는 데 응용하 는 의광학기술이 소개되고 있는데, 전경부 영역에서 부갑상 선 조직이 특정 파장의 빛을 받았을 때 형광 현상을 보인다 는 자가형광(autofluorescence) 현상이 소개된 이후로, ${ }^{4,5)}$ 이를 갑상선·부갑상선 수술에 적용하여 부갑상선을 시각적으로 찾 고자 하는 연구가 시작되었다. ${ }^{\circ}$ 이런 자가형광 영상은 합성된 광과민제를 인체 내로 주입하지 않아도 되기 때문에 아주 안 전한 방법으로 많은 주목을 받게 되었고, 최근에는 상용화된 다양한 기구를 이용하여 부갑상선의 형광 파장을 시각화하 는 광학기술이 접목되면서 수술 중에 부갑상선이 어디에 있는 지를 누구나 쉽게 확인할 수 있는 가능성을 보여주고 있다.-9)

본 연구진은 의료용이 아닌 디지털 일안 반사식 카메라 (digital single lens reflex, DSLR)를 이용하여 단 한 번의 촬 영으로 전체 수술 영역과 부갑상선의 자가형광을 동시에 보 여주는 이미징 기술을 처음 소개하였다. ${ }^{10}$ 또한, 부갑상선이 노출된 이후에 육안으로 의심되는 조직을 확인하는 수준을 넘어서 부갑상선이 지방이나 결체조직에 덮여 있어서 아직 노출되기 전 육안으로 확인되기 전 단계에서도 어디에 위치 하는지를 미리 예측할 수 있는 결과를 이미 보고하였다. ${ }^{11}$

이 연구에서는 갑상선 수술 중에 정상 부갑상선의 위치를 미리 예측하고 확인하여 안전하게 보존하는 과정에서 비디 오 영상 모니터링이 실시간으로 가능한지에 대한 가능성을
평가하고 그 결과를 보고하고자 한다.

\section{대상 및 방법}

Patients selection and equipments for near-infrared autofluorescence imaging

이 연구는 본 기관의 윤리심의위원회의 승인을 받은 후에 전향적으로 시행되었다(고신대학교 복음병원, 2017-04-040). 2015년 7월 2017년 1월까지 본원에서 갑상선 유두암으로 수 술을 받은 26명의 환자(남:여=5:21, 나이: 23 60세)에서 총 56 개의 정상 부갑상선을 대상으로 실험을 하였다. 수술 범위는 갑상선 일측엽 절제술을 받은 환자 18 명과 전절제술을 받은 환자는 8명이었고, 모든 환자에서 수술 부위의 예방적 중심 경부림프절 절제술을 시행하였다. 수술을 할 때 확인되어야 할 총 68 개의 정상 부갑상선 중에서 이미징 검사를 하기 전 에 술자의 육안으로 먼저 확인된 12 개의 부갑상선은 대상에 서 제외하였다(Fig. 1).

본 연구에서 사용된 이미징 기기는 본 연구진에 의해 자체적 으로 개발된 것으로, 1 대의 디지털 일안 반사식(DSLR) 카메라 와 1대의 발광 다이오드(light-emitting diode) 광원으로 이루 어져 있다. 카메라의 재원은 Canon사의 EOS Rebel T3(Tokyo, Japan)이고, 광원의 재원은 THORLABS사의 M780L3-C1 (Santa Barbara, CA, USA)이다. 광원에는 780-nm 파장을 협대역으로 통과시키는 필터 장치를 하여 이미징을 하는 목 표 영역에서 부갑상선을 활성화(excitation)시키고, 빛의 평 행 시준(collimation) 장치를 하여 광원에서 나오는 빛이 목 표 영역에 에너지를 균일하게 전달되도록 하였다.

\section{3-Stage guideline imaging procedure and data analysis}

수술은 전경부 피부 절개를 통한 통상적인 갑상선 수술법

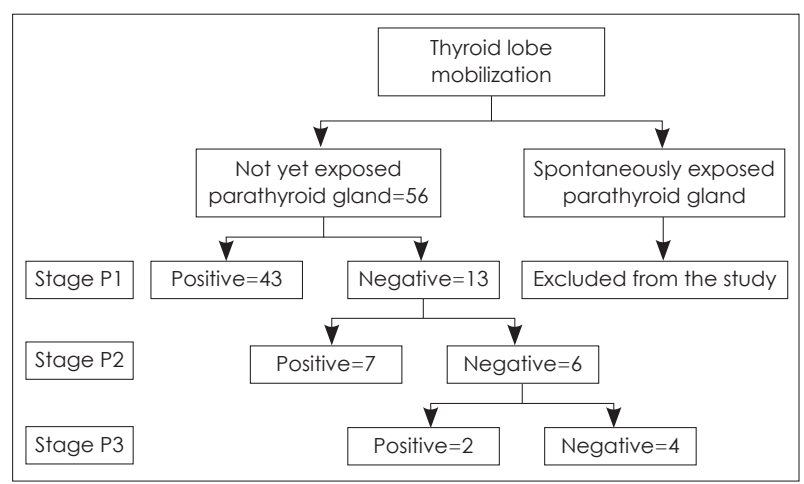

Fig. 1. Flowchart of the parathyroid gland identification process with near-infrared imaging and infrared illumination. 
에 따라 시행하였고, 수술 부위에서 노출될 것으로 예상되는 정상 부갑상선의 자가형광 이미징을 3단계를 나누어 시행하 였다. P1 단계는 갑상선의 외측부를 내측으로 견인을 하고 중갑상정맥을 결찰하지 않은 상태에서 부갑상선이 아직 노 출되지 않았지만, 기도외측부에 부갑상선이 존재할 것으로 예측되는 부위에서 촬영하는 것이다(Stage P1). P2 단계는 술 자가 부갑상선으로 강하게 의심이 되는 조직을 육안으로 확 인한 이후에 시행한 촬영이다(Stage P2). P2 단계에서는 P1 단계에서 형광이 확인되지 않았고, 갑상선 수술 경험이 많은 2 명의 술자에 의해 부갑상선을 육안으로 찾아서 노출시킨 후 에 촬영을 하였다. P3 단계는 P1과 P2에서 형광이 확인되지 않은 경우에 수술을 마치고 적출된 갑상선과 중심경부림프 절 조직을 촬영한 것으로, 최종 조직검사에서 부갑상선의 존 재 유무를 P3 단계의 결과와 비교하였다.

단계별 촬영에서 형광이 보이는 부위가 술자가 부갑상선이 라고 강하게 의심하는 부위와 일치하면 양성(positive)으로, 그렇지 않으면 음성(negative)으로 정의하였다. P1 단계에서 촬영한 이미지에서 형광이 보이는 부위가 있을 때 그 부위를 조심스레 박리해서 부갑상선 조직이 육안으로 확인되면 양 성으로 하였고, 그 이후의 P2와 P3 단계는 수술 시간이 길어 지는 것을 피하기 위해 추가로 시행하지 않았다. P1 단계에서 음성이면 P2 또는 P3 단계로 계속 진행하였다. P1 단계를 시 행하기 전에 부갑상선이 자연스레 노출되면서 육안으로 확인 된 경우는 연구 대상에서 제외하였다.

민감도(sensitivity)와 특이도(specificity)를 평가할 때 부 갑상선이 맞는지 확인하기 위한 조직검사에 대응하는 방법 으로 갑상선 수술 경험이 많은 술자 2 명의 육안적 검토 수준 (confidence level)이 높은 조사 방법을 적용하였다. 촬영된 비디오 영상에서 형광이 가장 잘 보이는 순간의 장면을 그림 파일로 저장한 후에 Image J 소프트웨어를 이용하여 부갑상 선 영역과 그 주위 조직 영역의 형광강도를 비교하여 parathyroid/background tissues ratio를 구하였고, 1보다 크면 부갑상선이 촬영한 이미지에서 밝게 보여 육안적으로 쉽게 구분되는 것으로 하였다.

\section{결 과}

P1 단계에서 부갑상선은 주변의 지방이나 결체조직에 파 묻혀 있는 상태이기 때문에 술자의 육안으로는 아직 확인이 되지 않았다. 근적외선 촬영을 하였을 때 갑상선, 기도, 근육, 피판 등의 수술 부위와 수술에 사용되는 도구들, 그리고 술 자의 손 등은 밝기의 차이가 있는 단일색상으로 표현되었고, 특정 부위에서 강한 밝기의 형광을 보이는 부분을 발견할 수 있었다. 술자는 근적외선 비디오 영상을 실시간으로 모니터 링하면서 강한 형광을 보이는 부분에서 지방 섬유 조직을 조 심스레 박리하였고, 부갑상선을 찾은 후에 강한 형광을 보이 는 부위가 부갑상선과 일치함을 증명하였다(Fig. 2, Supplementary Video 1).

P2 단계는 P1 단계에서 자가형광을 보이지 않은 경우에 술 자는 근적외선 비디오 영상을 보면서 기도-식도 사이 공간을 박리하였고, 자가형광이 나타나는 시점에서 확인된 조직이 부 갑상선 조직이 맞는지를 육안적으로 확인할 수 있었다(Fig. 3, Supplementary Video 2). P2 단계까지 자가형광이 확인되지 않은 6 개의 부갑상선 중에서 2개는 적출되어져 나온 중심경
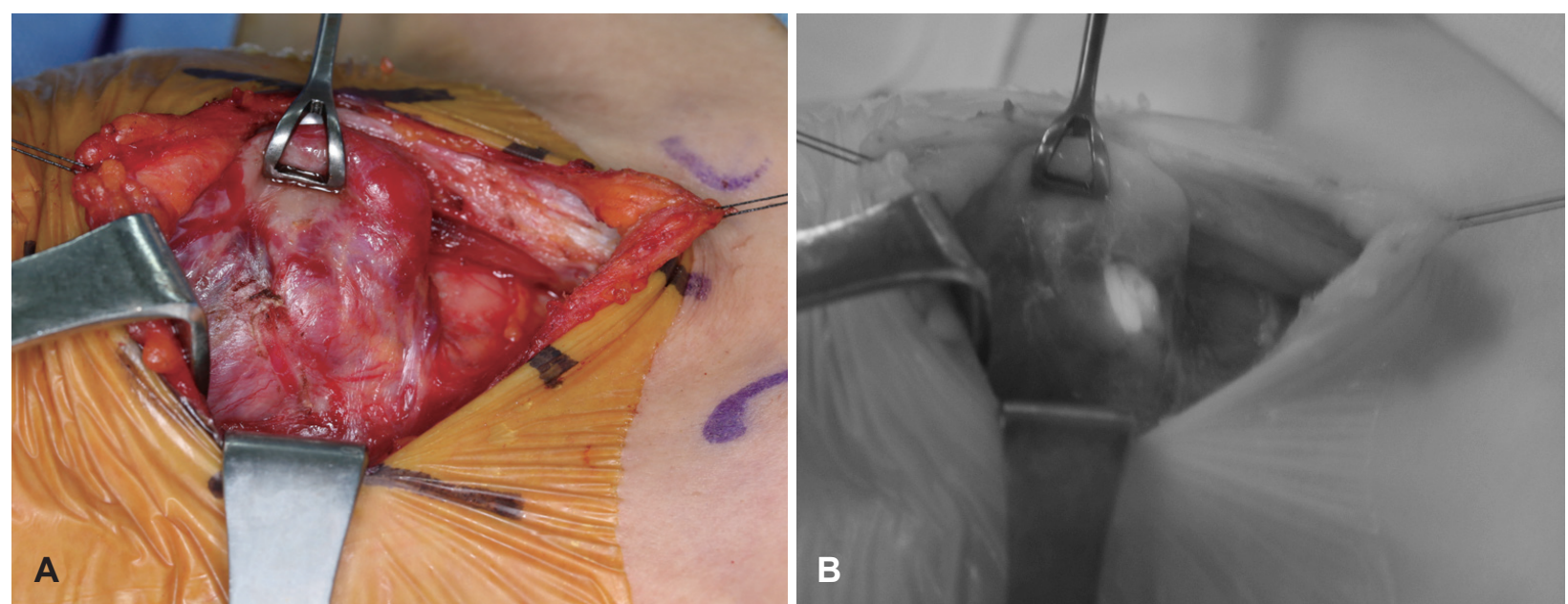

Fig. 2. NIR-IR image at the stage P1. Visible light image of right thyroid gland after paratracheal exposure (A). Parathyroid gland are not identified. Through the NIR-IR imaging, right Inferior parathyroid gland was observed with a distinct brightness difference from the surroundings (B). Luminous part in the NIR-IR imaging was matched with the parathyroid gland after dissection of superficial fat tissue. NIR: near-infrared, IR: infrared. 

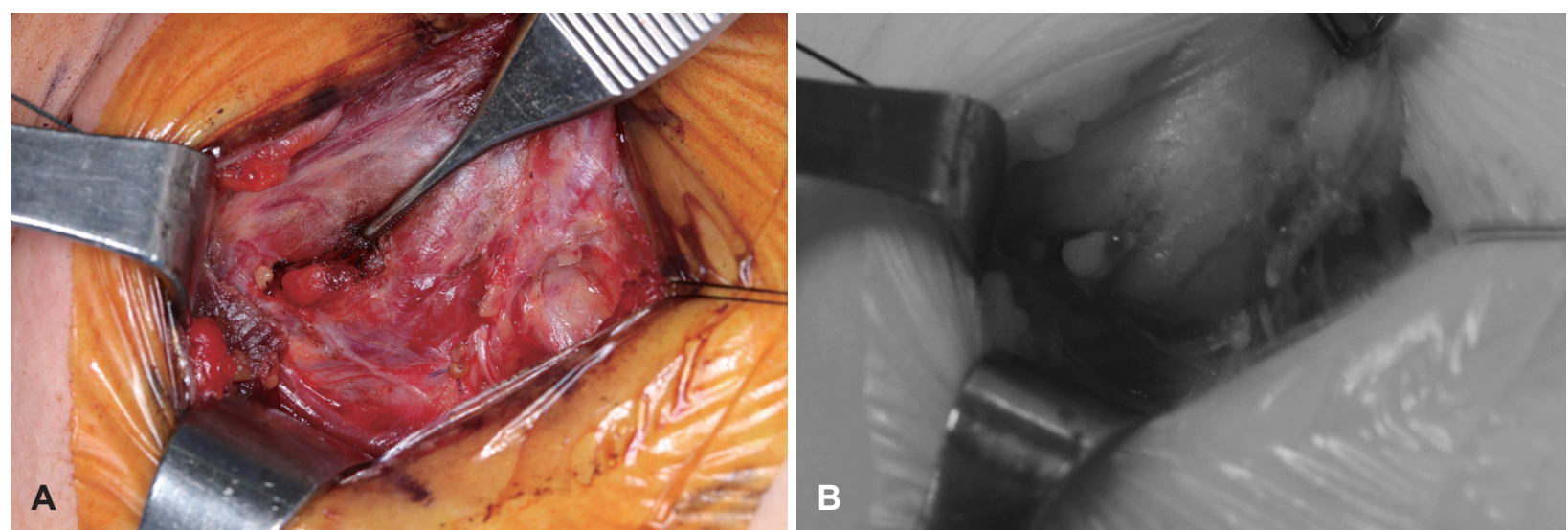

Fig. 3. NIR-IR image at the stage P2. Visible light image of right upper pole of the thyroid gland after exposure of parathyroid gland-like structure (A). The identifed mass was matched with bright part of NIR-IR imaging (B). NIR: near-infrared, IR: infrared.
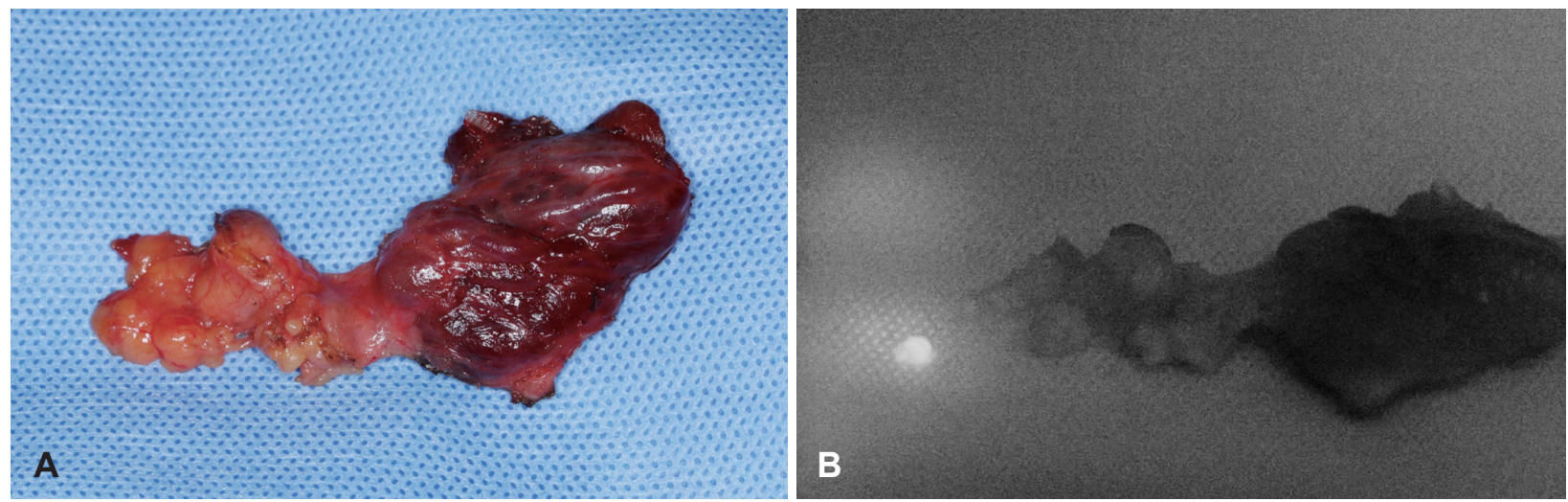

Fig. 4. NIR-IR image at the stage P3 in central neck dissection specimen. Parathyroid gland was contained in specimen with visible light image (A). With NIR-IR image, parathyroid gland mixed with fat tissue in specimen was detected (B). NIR: near-infrared, IR: infrared.

부 림프절 조직에서 자가형광이 확인되었고, 근적외선 비디 오 영상을 참고하면서 부갑상선을 찾은 뒤에 잘게 썰어서 흥 쇄유돌근에 자가이식을 해 주었다(Fig. 4, Supplementary Video 3).

P3 단계까지 술자의 육안으로도 찾을 수가 없었고 자가형 광을 확인되지 않은 4 개 조직의 최종 조직검사 결과에서 1 개 는 부갑상선 조직이 포함되어 있었고, 3 개는 부갑상선 조직이 없음을 확인하였다.

갑상선 수술을 받은 26 명의 환자에서 총 56 개의 정상 부 갑상선이 이 연구에 포함되었고, 부갑상선에 질환이 있는 경 우는 없었다. 수술이 진행되는 동안 56 개의 부갑상선 중에서 52 개는 자가형광을 보였고, 4 개는 수술을 마칠 때까지 어떠 한 형광 반응을 보이지 않았다. 수술을 마칠 때까지 자가형 광을 보인 52 개의 부갑상선 중에서 43 개는 아직 노출되지 않 은 상태에서도 형광 반응이 영상으로 보였고, 술자는 영상을 보면서 그 부분을 박리하여 부갑상선 조직이 있음을 확인할 수 있었다(P1, sensitivity=82.69\%). 다른 9예 중 7예는 술자 가 육안으로 부갑상선을 찾기 위해 박리를 하다가 형광이 보
이는 시점에서 부갑상선 조직이 노출되었음을 확인할 수 있 었고(P1+P2, sensitivity=96.15\%), 나머지 2예는 수술 후 적 출된 조직에서 확인되었다(P1+P2+P3, sensitivity=100.00\%). 자가형광이 확인되지 않은 경우에는 통상적으로 부갑상선이 위치하는 부위에서 육안적으로 찾기 위해 박리를 시도해 보았 으나 의심되는 조직은 발견되지 않았다(specificity=100.00\%).

수술이 진행되는 동안 자가형광 양성을 보였던 부분이 다 음 단계에서도 양성으로 보였지만 $(\mathrm{P} 1, \mathrm{P} 1+\mathrm{P} 2$, positive predictive value $=100.00 \%$ ), 적출된 조직에서 양성을 보였던 2예 는 형광을 보이는 일부 조직을 채취해서 동결 절편검사를 보 냈고, 그 결과에서 1 예는 지방 조직으로 판명되었다. 그리고, 최종적으로 자가형광이 음성이었던 4예 중 1 예는 적출된 조 직에 부갑상선이 있었음을 최종 조직검사에서 확인할 수 있 었다 $(\mathrm{P} 1+\mathrm{P} 2+\mathrm{P} 3$, positive predictive value $=98.08 \%$, nega tive predictive value $=75.00 \%$ ). 수술을 마칠 때까지 부갑상선 을 찾기 위한 자가형광 비디오 모니터링의 정확도(accuracy)는 $96.43 \%$ 였고, 그 결과를 요약하면 Table 1과 같다.

형광을 보인 52 개의 이미지에서 부갑상선이 주변 조직에 
Table 1. Results of statistical factors according to $P$ stage

\begin{tabular}{|c|c|c|c|c|c|c|}
\hline \multirow{2}{*}{ Characteristic } & \multicolumn{2}{|c|}{ Stage P1 } & \multicolumn{2}{|c|}{ Stage P1, P2 } & \multicolumn{2}{|c|}{ Stage P1, P2, P3 } \\
\hline & $\mathrm{n} /$ total & $\%$ & n/total & $\%$ & $n /$ total & $\%$ \\
\hline Sensitivity & $43 / 52$ & 82.69 & $50 / 52$ & 96.15 & $52 / 52$ & 100.00 \\
\hline Specificity & $4 / 4$ & 100.00 & $4 / 4$ & 100.00 & $4 / 4$ & 100.00 \\
\hline Positive predictive value & $43 / 43$ & 100.00 & $50 / 50$ & 100.00 & $51 / 52$ & 98.08 \\
\hline Negative predictive value & $4 / 13$ & 30.77 & $4 / 6$ & 66.67 & $3 / 4$ & 75.00 \\
\hline Accuracy & $47 / 56$ & 83.93 & $54 / 56$ & 96.43 & $54 / 56$ & 96.43 \\
\hline
\end{tabular}

Stage P1: imaging before identification of the gland by direct visualization, stage P2: imaging after identification, stage P3: imaging in the removed specimen

비해서 2배 이상 밝게 보여 육안으로 쉽게 확인이 되었다. 수 술 환자 중에서 부갑상선이 2개 이상 적출된 경우는 없었으 며, 수술 후 부갑상선 기능은 정상을 유지하였다. 외부의 형 광 조영제를 사용하지 않았기 때문에 특별한 전 처치는 없었 다. 근적외선 촬영을 위한 장비는 수술 전에 미리 준비해 놓 은 상태에서 수술 중 각 단계별로 수술등을 끄고 실내등은 켜 놓은 상태에서 모니터를 통해 자가형광이 보이는지 확인 하면서 수술을 정상적으로 진행하였기 때문에 추가되는 시 간은 5 분 미만으로 전체 수술 시간에는 영향을 주지 않았다.

\section{고 찰}

수술 중에 부갑상선을 확인(identification)하는 것은 두 가지 경우에 필요하다. 첫 번째는 갑상선 수술 중에 정상 부 갑상선을 손상 없이 안전하게 보존하여 술 후 기능저하증을 예방하는 것이고, 두 번째는 기능항진증으로 이환된 부갑상 선 조직이 어디에 있는지 찾는 것이다.

갑상선 질환의 치료로 갑상선 절제 수술을 할 때 정상 부 갑상선은 수술 부위의 지방이나 결체조직들과 구별을 하기 가 쉽지 않고, 조직을 다룰 때 손상을 받거나 의도치 않게 제 거되기도 하고 혈액 공급이 방해되어 수술 후 기능이 소실되 는 경우도 있다. 그래서 갑상선 수술 후에 부갑상선 기능저하 증이 일시적으로는 20 35\%, 영구적으로는 1 5\%의 빈도로 보고되고 있다. ${ }^{12,13)}$ 이를 예방하기 위한 방법은 술자가 육안 으로 부갑상선을 확인하고 공급혈관을 다치지 않게 주의깊 게 박리하여 보존하는 술식인데, 그 결과는 술자의 경험에 따 라 매우 다르게 보고되는 실정이다. ${ }^{14)}$ 또는 수술 중 동결절편 검사로 확인을 할 수 있지만 조직 일부를 잘라서 검사를 의 뢰하는 침습적인 방법이라서 물리적인 손상을 주게 되고, 생 리식염수에 담궈서 뜨는지 가라앉는지 알아볼 수도 있으나 적출된 부갑상선을 자가이식할 때 도움이 되는 방법이다. 이 런 방법들은 부갑상선으로 가는 혈류를 보존하여 술 후 기 능저하를 예방하는 방법으로는 도움이 되지 않는다.

부갑상선 일차적 기능항진증이 발현되는 빈도는 주로 하
나의 선종이 80 85\%, 다수의 증식증이 5 15\%이다. 일차 치 료는 의심되는 부갑상선 조직을 모두 제거하는 수술인데, 위 치가 일정하지 않아 수술 중 육안으로 찾기가 어렵거나, 이소 성 조직이 다양하게 분포되는 경우에는 병적 조직을 남길 수 도 있어서, 수술 이후에도 기능항진증이 조절되지 않아 치료 에 실패하는 어려움을 겪게 된다. ${ }^{15)}$ 수술 중에는 부갑상선호 르몬의 혈중 농도를 시간대별로 측정하는 방법(intraoperative parathyroid hormone monitoring)이 남은 부갑상선 조직의 기능을 평가하고, 수술적 치료가 잘 되었는지를 평가하는 유 일한 방법이다.

최근에는 광학 기술의 접목을 통해 수술 중에 부갑상선을 쉽게 찾고 그 기능을 객관적으로 평가하려는 연구가 많이 소 개되면서 임상 의사들도 이 주제에 깊은 관심을 보이고 있다. 부갑상선이 근적외선 파장대에서 자가형광 현상(autofluorescence)이 있다는 것은 2011년에 처음 보고되었다. 부갑상 선에 근적외선의 특정 파장 $(785 \mathrm{~nm})$ 을 비춰주면 그 빛을 흡 수하면서 에너지가 만들어지고(excitation) 그 에너지가 약간 긴 파장 $(822 \mathrm{~nm})$ 의 빛으로 여기(emission)되는 현상이다. ${ }^{4}$

이 이론을 응용하여 부갑상선에서 여기되는 빛을 근적외 선 카메라로 영상을 만들고 부갑상선의 존재를 확인하는 방 법이 소개되었다. 주변의 지방, 근육, 그리고 기도는 형광이 없어서 어둡고 보이고 갑상선은 형광이 약하게 있어서 영상 으로는 구별이 안 되지만, 부갑상선은 강한 형광을 보이는 특 징이 있고 갑상선에 비해 최소 2 배 이상 밝게 보여서 누구나 시각적으로 쉽게 구별이 가능하였다. ${ }^{6}$ 부갑상선의 자가형광 현상을 보여준 이런 기술은 외부 주입 형광물질을 사용하지 않고 인체에 무해한 수준의 광원을 이용해 사진 촬영만으로 부갑상선을 구별할 수 있어서 비침습적이고, 수술 시간에 거 의 영향을 주지 않으며, 정확도가 매우 높기 때문에 임상에 서 안전하게 사용될 가능성과 유용성이 높게 평가되었다. 그 리고 무엇보다도 사람의 부갑상선을 대상으로 조영제를 사 용하지 않는 자가형광을 수술 중에 촬영한 첫 번째 연구라는 점에서 매우 큰 의미가 있다. 하지만, 부갑상선이 밝게 보여서 부갑상선이 있다는 것은 알 수 있었지만(identification), 주변 
의 다른 조직은 자가형광이 없어 검게 나오기 때문에 부갑상 선이 어디에 있는지는(localization) 알 수는 없었다, 그래서, 동일한 영역을 가시광선으로 촬영한 사진과 근적외선 사진 을 서로 겹쳐서(overlay) 하나의 사진으로 재구성한 이후에 실제 수술 시야에서 부갑상선이 어디에 위치하며 주변 조직 과 어떤 관계를 가지는지를 알 수 있다는 한계가 있었다.

이를 해결하기 위해 본 연구진은 이전 연구에서 부갑상선 에 비추는 광원에 더해 넓은 근적외선 파장대의 광원을 동시 에 수술 부위에 비춰주고 촬영하는 방법을 제안하였고, 단 한 번의 촬영으로 전체 수술 영역에서 부갑상선의 자가형광 이 어디에서 보이는지를 실시간으로 보여주는 기술을 2016년 에 개발하여 결과를 보고하였다. ${ }^{10)}$ 이 연구는 디지털 일안 반 사식 카메라에 부갑상선에서 여기되는 빛만을 통과시키는 필 터를 렌즈에 부착하는 방법으로 촬영되었으며 자체적으로 개발된 카메라를 이용한 최초의 실험이었다. 그리고 비슷한 시기에 형광 촬영을 위해 이미 상용화되어 있던 Fluobeam ${ }^{\circledR}$ (Fluoptics, Grenoble, France) 또는 NIR/ICG endoscopic system $^{\circledR}$ (KARL STORZ, Tuttlingen, Germany)을 이 분야 에 응용하여 부갑상선의 확인과 위치를 평가하는 결과도 보 고되었다. ${ }^{7-9)}$

임상적으로 실제 수술을 진행할 때 부갑상선이 노출되기 전 단계에서 그 위치를 미리 예측할 수 있다면 수술면을 정 확하고 신속하게 결정하는 데 도움이 된다. 섬세하게 박리하 여 부갑상선으로 가는 공급혈관을 보존하는 술식이 중요하 지만 이는 전적으로 경험에 의존하는 것이고, 육안으로 확인 하기 위해 부갑상선의 표면을 불필요하게 노출하며 박리해야 하는 경우도 있어서 부갑상선을 잘 남겼음에도 불구하고 기 능저하증이 올 수 있다. 또한 조심해서 박리를 하더라도 적출 되는 조직에서 부갑상선이 발견되는 경우도 종종 있기 때문 에 안전한 수술면을 미리 예측하는 것은 술자로 하여금 신속 하고 편안하게 수술을 진행하는 데 도움이 되며, 수술 후 부갑 상선 기능저하증을 줄이는 데도 유용할 것으로 생각한다. ${ }^{16,17)}$

본 연구에서는 육안으로 확인된 부갑상선을 형광으로 확 인하는 기존 연구와 달리 자연스레 노출되는 부갑상선을 제 외한 모든 경우에 대하여 육안으로 확인하기 전 단계에서 촬 영을 먼저 하여 그 위치를 예측하는 '지도작성법(mapping)' 으로 진행하였다. 그 정확도(accuracy)는 P1, P2 단계에서 각 각 83.93\%, 96.43\%였다. 임상적으로 이전 연구에서 육안으로 확인된 이후에 확인이 가능하였던 P2 단계의 정확도를 고려 하면 노출되기 전 단계인 P1에서 다소 낮기는 하지만 육안으 로 보이지 않는 상황임에도 불구하고 위치를 예측할 수 있다 는 점에서 비교적 정확한 수치라고 판단이 된다. 또한 기술적 으로는 이전 연구에서 4 초당 1 프레임으로 촬영한 것에 비교
하면 자가형광은 강도가 매우 약해서 동영상 촬영을 위해 1 초 당 20 프레임 이상으로 설정하여 노출 시간을 매우 짧게 하여 야 되고, 카메라의 초첨 설정이 자동으로 되어야 하는 문제점 을 해결하였다는 데 그 의의가 있고, 현재 상용화된 기구들 에 비해 훨씬 기술적으로 진보된 상태라고 판단된다. ${ }^{10,11,18)}$

적출된 조직에서 발견되는 부갑상선은 술자가 매우 조심 을 하여도 의도치 않게 떨어져 나오는 경우인데 이런 경우에 도 자가형광 현상이 있기 때문에, 술 중 육안으로 보이지 않 고 형광촬영에서도 확인이 안 되었지만 P3 단계에서 확인이 된다면 자가이식을 결정할 때 도움이 될 수 있다. 자가이식을 하려면 의심되는 조직을 일부 잘라서 동결절편 검사로 확인 을 해야 하는데, 이에 드는 비용과 시간 또는 재검의 가능성 을 줄여줄 수 있다. 본 연구에서 P3 단계까지의 민감도는 $100.00 \%$, 정확도는 $96.43 \%$ 이고, 수술 중에 부갑상선을 찾지 못한 경우 적출된 조직에서 부갑상선을 찾을 가능성이 높기 때문에, 자가이식을 신속하게 결정하여 장기적으로 기능저하 증을 예방하는 데 도움이 될 것으로 생각한다.

이런 기술을 잘 사용하면 술자가 수술의 경험이 부족하거 나 수술 건수가 그리 많지 않는 기관에서 합병증을 줄이는 데 유용할 것으로 생각되고, 갑상선 질환이 광범위하여 수술 범위가 넓거나 림프절 전이가 많아 림프절 절제술을 적극적 으로 하여야 하는 경우에는 경험이 많은 술자라 하더라도 부 갑상선 조직이나 혈관구조에 손상을 줄 가능성이 있어 이를 예방하는 데 도움을 줄 것으로 예상한다. 본 연구에서 모든 환자들은 수술 후에 부갑상선 기능저하증이 없었다. 미국 갑 상선학의 최신 의견에 의하면,9) 임상적인 부갑상선 기능항진 증은 부갑상선 호르몬이 $12 \mathrm{pg} / \mathrm{mL}$ 이하이면서 저칼슘혈증 과 그에 관련된 증상이 동반되는 경우를 의미하는데, 모든 환자들이 이 기준에 해당하지는 않아서 수술 후 부갑상선 기능은 정상으로 유지되었다고 판단하였다. 또한 수술 후 부 갑상선의 기능이 잘 유지되는지를 알기 위해서는 갑상선 전 절제술을 시행받은 환자를 대상으로 하여야 하는데, 이 연구 에서는 갑상선 부분 절제술과 전 절제술을 받은 환자들이 혼재되어 있기 때문에 수술 후 부갑상선 호르몬과 칼슘 수치 를 비교하여 통계적으로 유의미함을 증명하기가 쉽지 않았 다. 향후에 이 기술을 적용하기 전과 후의 갑상선 전 절제술 을 받은 환자만을 대상으로 하여 수술 전과 후의 부갑상선 기능을 평가하는 대규모 연구가 필요할 것이다.

기존의 상용화된 형광 영상 촬영 장치들의 큰 단점 중의 하나는 수술실의 모든 빛을 차단하여야 한다는 점이다. 수술 중 술자의 육안으로 부갑상선으로 강하게 의심되는 조직을 확인한 후에 부갑상선이 맞는지 확인하기 위해 촬영을 하려 면 수술을 잠시 멈추고 카메라를 수술 부위에 가까이 위치 
한 상태에서 수술등(surgical light)과 실내등(room light)을 모두 소등(switch off)한 상태에서 촬영해야 한다. 그 이후에 다시 점등하여 수술을 진행해야 하는 번거로움 때문에 수술 진행에 방해가 되고 불필요하게 수술 시간이 길어질 수 있다. 또한 암실 환경에서 촬영된 형광 영상에서 부갑상선의 존재 를 알 수는 있지만, 다시 점등한 이후 수술 필드에서 정확한 위치를 일치시키기가 어렵기 때문에 정확하지 않을 수 있는 단점을 고려해야만 했었다. ${ }^{18)}$ 또한 한 부분에 다수의 부갑상 선이 중첩되어 있으면 약한 형광이 강한 형광에 묻혀 혼란스 러울 수 있고, 이소성으로 위치하는 경우에는 사진 촬영으로 찾기가 어려울 수 있다. 그러나 본 연구에서는 비록 수술등은 소등하여야 하나 실내등은 켠 상태로 촬영이 가능하여 암실 을 만들지 않아도 되어 수술 진행에 거의 영향을 주지 않았 고, 형광 영상에서 표시된 부분을 동영상을 보며 실제 수술 필드에서 일치되는 위치에 정확하게 표시를 할 수 있었기 때 문에 주변 구조와의 관계를 이해하는 데 많은 도움을 주었다.

거의 모든 상용화된 영상 장치는 조직에 직접 닿지 않지만 초점 거리가 수술 영역에서 $30 \mathrm{~cm}$ 이내여서 무균 상태를 유 지하기 위해 카메라를 소독하거나 소독포로 카메라를 감싸 는 별도의 준비가 필요하다. 그러나, 본 연구에 사용된 카메 라의 초첨 거리는 약 $100 \mathrm{~cm}$ 정도로 설정되어 있어 일반적으 로 수술면에서 안전한 거리인 $50 \mathrm{~cm}$ 를 충분히 확보하여 멸 균을 따로 할 필요가 없으며 부가적인 준비물이 필요하지 않 았다. ${ }^{20,21)}$

비록 이 부갑상선의 자가형광 신호가 매우 특이적이라고 알려져 있지만, 최근까지 보고된 바에 의하면 예외적인 위양 성(false positive)이 몇 가지 있다. 먼저 갑상선 조직도 동일한 파장대에서 자가형광을 가지고 있다. 하지만 부갑상선이 형 광의 강도가 2 12배 정도 강하기 때문에, 부갑상선이 갑상선 보다 횔씬 밝게 보여서 확연히 구별이 된다. 갑상선 조직 중 에서도 부분적으로 밝게 보이는 부분이 있는데, 이는 콜로이 드 낭종(colloidal cyst)으로 알려져 있다. 콜로이드 낭종의 형광은 갑상선 조직 중에서도 밝게 보이기 때문에 갑상선 내 에 위치한 부갑상선으로 잘못 해석될 수 있으나, 형광의 경계 가 불분명하다는 차이점이 있다. 마지막으로 갈색지방조직도 근적외선 영상에서 밝게 보일 수 있다. 그러나 이 조직은 근 적외선을 조사하지 않고, 일반 가시광을 비추어도 모니터 영 상에서는 형광 현상과 유사하게 밝게 보이기 때문에 근적외 선에 비특이적인 현상으로 이해된다. 형광 강도를 표준화하 여 정량적으로 분석한 보고는 아직 없어서 술자의 주관적인 판단에 의존해야 하기 때문에 이 영상을 해석할 때에는 약간 의 경험이 필요하다. ${ }^{7)}$ 근적외선 자가형광을 영상으로 보여주 는 이 기술로 아직 미국 식품의약국(FDA)을 비롯하여 공인
된 기구에서 승인을 받은 의료기기는 아직 없다. 현재의 기술 적인 한계를 극복하고 임상에서의 안정성과 유용성에 대한 지속적인 연구를 통해 해결해야 할 것이다.

본 연구는 수술 중 실내등을 켠 상태에서도 부갑상선의 자 가형광 현상을 실시간으로 비디오 모니터링을 할 수 있다는 것을 보여준 첫 번째 연구이다. 기존의 상용화된 장비들의 한 계를 극복하는 기술적인 진보가 있었고, 근적외선의 조직 침 투 특성을 이용하여 부갑상선이 노출되기 전 단계에서도 높 은 정확도로 그 위치를 미리 예측하여 수술면을 쉽게 결정할 수 있었다. 이 혁신적인 광학기술은 향후 부갑상선을 쉽게 찾 고 안전하게 보존하여 수술 후 합병증을 줄이는 데 많은 도 움을 줄 것으로 기대한다.

\section{Supplementary Video Legend}

Video 1. NIR-IR video at the stage P1.

Video 2. NIR-IR video at the stage P2.

Video 3. NIR-IR video at the stage P3.

\section{Supplementary Materials}

The Data Supplement is available with this article at https://doi. org/10.3342/kjorl-hns.2019.00556.

\section{Acknowledgments}

None.

\section{Author Contribution}

Data curation: Yoon Soo Seo. Methodology: Hyoung Shin Lee, Yekeun Kim. Writing — original draft: Sung Won Kim. Writingreview \& editing: Yeh-Chan Ahn, Kang Dae Lee.

\section{ORCID}

Kang Dae Lee https://orcid.org/0000-0003-3143-1180

\section{REFERENCES}

1) Ahn D, Sohn JH, Kim JH, Park JY, Park J. Inadvertent parathyroidectomy during thyroid surgery for papillary thyroid carcinoma and postoperative hypocalcemia. J Korean Thyroid Assoc 2012;5(1):65-72.

2) Lin DT, Patel SG, Shaha AR, Singh B, Shah JP. Incidence of inadvertent parathyroid removal during thyroidectomy. Laryngoscope 2002;112(4):608-11.

3) Sasson AR, Pingpank JF Jr, Wetherington RW, Hanlon AL, Ridge JA. Incidental parathyroidectomy during thyroid surgery does not cause transient symptomatic hypocalcemia. Arch Otolaryngol Head Neck Surg 2001;127(3):304-8.

4) Paras C, Keller M, White L, Phay J, Mahadevan-Jansen A. Nearinfrared autofluorescence for the detection of parathyroid glands. J Biomed Opt 2011;16(6):067012.

5) McWade MA, Paras C, White LM, Phay JE, Mahadevan-Jansen A, Broome JT. A novel optical approach to intraoperative detection of parathyroid glands. Surgery 2013;154(6):1371-7.

6) McWade MA1, Paras C, White LM, Phay JE, Solórzano CC, Broome JT, et al. Label-free intraoperative parathyroid localization with nearinfrared autofluorescence imaging. J Clin Endocrinol Metab 2014; 
99(12):4574-80.

7) De Leeuw F, Breuskin I, Abbaci M, Casiraghi O, Mirghani H, Ben Lakhdar A, et al. Intraoperative near-infrared imaging for parathyroid gland identification by auto-fluorescence: A feasibility study. World J Surg 2016;40(9):2131-8.

8) Falco J, Dip F, Quadri P, de la Fuente M, Rosenthal R. Cutting edge in thyroid surgery: Autofluorescence of parathyroid glands. J Am Coll Surg 2016;223(2):374-80.

9) Ladurner R, Sommerey S, Al Arabi N, Hallfeldt KK, Stepp H, Gallwas JK. Intraoperative near-infrared autofluorescence imaging of parathyroid glands. Surgical Endoscopy 2017;31(8):3140-5.

10) Kim SW, Song SH, Lee HS, Noh WJ, Oak C, Ahn YC, et al. Intraoperative real-time localization of normal parathyroid glands with autofluorescence imaging. J Clin Endocrinol Metab 2016;101 (12):4646-52

11) Kim SW, Lee HS, Ahn YC, Park CW, Jeon SW, Kim CH, et al. Nearinfrared autofluorescence image-guided parathyroid gland mapping in thyroidectomy. J Am Coll Surg 2018;226(2):165-72.

12) Mathonnet M, Cuerq A, Tresallet C, Thalabard JC, Fery-Lemonnier $\mathrm{E}$, Russ G, et al. What is the care pathway of patients who undergo thyroid surgery in France and its potential pitfalls? A national cohort. BMJ Open 2017;7(4):e013589.

13) Christou N, Mathonnet M. Complications after total thyroidectomy. J Visc Surg 2013;150(4):249-56.
14) Mittendorf EA, McHenry CR. Complications and sequelae of thyroidectomy and an analysis of surgeon experience and outcome. Surg Technol Int 2004;12:152-7.

15) Ryan S, Courtney D, Moriariu J, Timon C. Surgical management of primary hyperparathyroidism. Eur Arch Otorhinolaryngol 2017; 274(12):4225-32.

16) Manouras A, Markogiannakis $H$, Lagoudianakis E, Antonakis $P$, Genetzakis M, Papadima A, et al. Unintentional parathyroidectomy during total thyroidectomy. Head Neck 2008;30(4):497-502.

17) Du W, Fang Q, Zhang X, Cui M, Zhao M, Lou W. Unintentional parathyroidectomy during total thyroidectomy surgery: A single surgeon's experience. Medicine 2017;96(11):e6411.

18) Thomas G, McWade MA, Nguyen JQ, Sanders ME, Broome JT, Baregamian N, et al. Innovative surgical guidance for label-free realtime parathyroid identification. Surgery 2019;165(1):114-23.

19) Orloff LA, Wiseman SM, Bernet VJ, Fahey TJ III, Shaha AR, Shindo ML, et al. American thyroid association statement on postoperative hypoparathyroidism: Diagnosis, prevention, and management in adults. Thyroid 2018;28(7):830-41.

20) Zhu B, Sevick-Muraca EM. A review of performance of nearinfrared fluorescence imaging devices used in clinical studies. Br J Radiol 2015;88(1045):20140547.

21) Price P, Frey KB. Microbiology for surgical technologists. Clifton Park, NY: Delmar Learning;2003. 